\title{
Rational limits on genomic patents
}

\author{
John H. Barton
}

Genomics and the availability of high-speed automated sequencing capability pose a new generation of questions for patent law. Under what circumstances should an expressed sequence tag (EST) be patentable, and should such a patent give rights against the whole gene containing the EST? What about singlenucleotide polymorphisms (SNPs)? What about claims on computer exploration of a genome? At the same time that many of us find ourselves concerned about such patents, few of us argue against patents on therapeutic proteins or the gene sequences associated with these proteins. It is hard to imagine how firms would be willing to invest in clinical trials for products on such proteins unless they had exclusivity.

The standards for granting patents require that the invention be new, nonobvious, and useful, and that the patent adequately describe the invention and how to practice it. Of these standards, it is the utility doctrine that currently provides the leading approach to deciding which kinds of genomic patents should be granted. The US Patent and Trademark Office's Revised Interim Utility Examination Guidelines, published in December 1999, suggest that a SNP or an EST associated with a well-defined function is patentable, whereas a more abstract or less well-understood SNP or EST is not patentable. Yet, there may be need for additional limits. Three further limitations deserve consideration; each responds to insights that many of us share about patent law, each could be implemented in actual patent doctrine, and each will be raised in many patent-law contexts outside genomics.

The first limit is to consider whether automated gene sequencing really "invents or discovers" within the meaning of the patent law. Not long ago, genes were laboriously sequenced with enormous human input; now they are sequenced automatically. Is the working of the machines really invention? What about algorithms that might mine the sequences for open reading frames and distinguish exons and introns? Certainly, in a reaction against a "flash of genius standard," the patent law states explicitly that nonobviousness "shall not be negatived by the manner in which the invention was made." And enormous ingenuity goes into the design of sequencing systems. Yet, we wonder whether

John H. Barton is George E. Osborne Professor of Law, Stanford University, Stanford, CA 94305 (jbarton@leland.stanford,edu). real invention is taking place-and, as the capabilities of computers increase, will ultimately have to develop thoughtful principles for invention by machine.

A second possible limit derives from the use of SNPs and ESTs as research tools. As tools, their economic value is in helping discover a pharmaceutical product; it is the product that will provide a monopoly rent, and that monopoly rent must be divided between the developer of the various tools used and the developer of the product. From an economic perspective, a tool such as a SNP or an EST should be patentable if the benefit of such a patent in strengthening incentives to develop genomic information is greater than the costs of the patent in foreclosing others' ability to use the information about the genome. There must be a balance. The incentive benefit has been quite significant, and is reflected in the ability of firms such as Celera Genomics (Rockville, MD) and Incyte Genomics (Palo Alto, CA) to raise capital and to greatly speed the sequencing of various genomes. The costs are quite significant as well and include the need to obtain permission from the holder of rights to a research tool in order to engage in further research or develop a product. If a holder of a research tool withholds a license in an effort to obtain a larger share of the ultimate economic benefits, the further research may not be undertaken, even though it may be of value to the society. The balance between these costs and benefits should be taken into account in deciding the patentability of ESTs or SNPs or other research tools. This can be done under traditional patent law doctrines by, for example, finding "nonobviousness" less readily satisfied if the initial invention is relatively easy or finding "utility" less readily satisfied if the ultimate application of the information or tool is unknown.

The third possible limit is the most fundamental and involves our judgment as to what is a patentable invention and what is an unpatentable piece of information or law of nature. The tension is already difficult in genomics, for a gene sequence is both a piece of information and a description of a physical chemical. It will become much more difficult with the increasing integration of genomics and software. Recent decisions of the Court of Appeals for the Federal Circuit, the key US court for patents, are extending patent law to intellectual processes, and permitting patents on increasingly abstract concepts. One can now patent a computer program that leads to a financially important number ${ }^{1}$, or a com- puter tag that facilitates the billing of calls ${ }^{2}$. These new doctrines are likely to undercut the traditional distinction between an invention and a principle of nature and may lead to a variety of patent claims designed to completely preempt others' use of particular kinds of information, be it genomic or medical or economic. Assuming that novelty and nonobviousness are satisfied, patents seem likely to be granted, for example, on the use of particular physiological indicators for diagnostic purposes or of specific economic indicators for forecasting purposes.

At some point, this is going too far, and it becomes essential to reemphasize the fundamental principle that information itself cannot be patented. This principle might be interpreted to require that a patent never diminish the amount of usable information in the public domain. This principle is not only logical, it is required by common sense and is a direct application of the prohibition against patenting laws of nature stated in Diamond v. Chakrabarty ${ }^{3}$. The principle is reflected in the disclosure role of the patent system, under which information about an invention must be disclosed. And it may have constitutional dimensions. In upholding the point that copyright law can only protect the expression of information and cannot protect the underlying information, the Supreme Court has stated that "originality" is a constitutional requirement, and that "one who discovers a fact is not its 'maker' or 'originator"' 4 . As for the other limitations, the detailed implications of this principle are difficult to work out. For example, the principle should certainly be applied to prohibit patents that keep anyone from using the information in gene sequences for research. At the same time, the principle should not be interpreted to bar exclusive rights over a product based on a gene sequence, that is, a therapeutic protein.

Genomics and informatics are pushing the patent system into uncharted areas. As it enters these areas, it will need new guidelines in order intelligently to apply the traditional intellectual property standards. Unless these guidelines are developed well, the system may hurt innovation more than it helps it.

\footnotetext{
1. State Street Bank \& Trust Co. v. Signature Financial Group, Inc., 149 F.3d 1368 (CAFC 1998).

2. AT\&T Corp. v. Excel Communications, Inc., 172 F.3d. 1352 (CAFC 1999).

3. Diamond v. Chakrabarty, 447 U.S. 303 (1980).

4. Feist Pub'l, Inc. v. Rural Tel. Service Co., 499 U.S.
} 340 (1991). 